\title{
PENGARUH IMPLEMENTASI KEBIJAKAN PERTAMBANGAN TERHADAP EFEKTIVITAS PENANGANAN KUALITAS LINGKUNGAN HIDUP PADA DINAS PEKERJAAN UMUM, ENERGI DAN SUMBER DAYA MINERAL KOTA PALU
}

\author{
Ahmad Averus dan Andi Pitono \\ Pascasarjana Institut Pemerintahan Dalam Negeri \\ E-mail : ahmad_averus@yahoo.co.id
}

\begin{abstract}
ABSTRAK Adanya kegiatan pertambangan batu berdampak pada kualitas lingkungan hidup. Karena itu, Pemerintah Daerah Kota Palu mengeluarkan kebijakan yang mengatur kegiatan pertambangan batu. Namun dalam implementasi kebijakan belum optimal. Penelitian ini mengacu pada model implementasi kebijakan menurut Smith yang memiliki empat komponen yaitu idealised policy, target groups, implementing organization, dan environmental factor. Penelitian ini menggunakan pendekatan kuantitatif yakni pengambilan data melalui kuesioner, observasi, wawancara dan dokumentasi. Data yang dianalisis adalah data yang diperoleh dari kuesioner penelitian kemudian dianalisis secara statistik structural equation modeling (SEM). Pada pembahasan hasil penelitian berdasarkan atas data kuesioner sekaligus data pendukung kuesioner yaitu dari hasil wawancara, observasi dan dokumentasi. Adapun unit analisis dalam penelitian ini adalah pegawai Dinas Pekerjaan Umum, Energi Dan Sumber Daya Mineral Kota Palu. Sedangkan teknik penarikan sampel yang digunakan adalah stratified random sampling. Hasil penelitian menunjukkan bahwa implementasi kebijakan pertambangan secara signifikan berpengaruh terhadap efektivitas penanganan kualitas lingkungan hidup. Hal ini dapat diartikan bahwa pada prinsipnya implementasi kebijakan pertambangan memiliki peran yang sangat penting untuk mencapai efektivitas penanganan kualitas lingkungan hidup di Kota Palu Provinsi Sulawesi Tengah.

Kata kunci : implementasi kebijakan, kualitas lingkungan hidup
\end{abstract}

THE INFLUENCE OF POLICY IMPLEMENTATION IN THE MANAGEMENT OF MINING OPERATIONS ON THE EFFECTIVENESS OF THE HANDLING OF ENVIRONMENTAL QUALITY AT OFFICIAL PUBLIC WORKS, ENERGY AND MINERAL RESOURCE PALU CITY

ABSTRACT The presence of stone mining activities have an impact on environmental quality. Therefore, the Local Government Palu issued a policy that regulates the activities of stone mining. But in policy implementation is not optimal. This study refers to the model of policy implementation by Smith who has four components, namely idealised policy, target groups, the implementing organization, and environmental factors. This study uses a quantitative approach that is data collection through questionnaires, observation, interviews and documentation. The data analyzed were obtained from questionnaire data were analyzed statistically study structural equation modeling (SEM). In discussing the results of research based on questionnaire data as well as supporting data from the interview questionnaire, observation and documentation. The unit of analysis in this study were employees of the Office of Public Works, Energy and Mineral Resources of Palu City. While the sampling technique used was stratified random sampling. The results showed that the policy implementation of the mining have significant impacts on the effectiveness of the handling of environmental quality. This could mean that in principle the policy implementation of the mining has a very important role to achieve effective management of environmental quality in the city of Palu, Central Sulawesi Province.

Key words : policy implementation, environmental quality 


\section{PENDHULUAN}

Kota Palu memiliki berbagai sumber daya alam yang salah satunya ialah pertambangan batu. Sehingga Kota Palu sebagai salah satu daerah di Provinsi Sulawesi Tengah dikenal sebagai penghasil sekaligus pemasok batu yang berkualitas. Pemerintah Daerah Kota Palu dalam mengantisipasi berbagai potensi kerusakan lingkungan hidup sebagai dampak kegiatan pertambangan batu tersebut, telah mengeluarkan kebijakan dalam bentuk Peraturan Daerah Kota Palu Nomor 18 Tahun 2003 tentang Pengelolaan Usaha Pertambangan Umum. Sasaran yang dikehendaki dengan adanya kebijakan pertambangan tersebut adalah setiap masyarakat di Kota Palu dapat memanfaatkan sumber daya alam seperti pertambangan batu, dan dari adanya pemanfaatan sumber daya alam tersebut sehingga dapat memberikan manfaat bagi peningkatan sumber pendapatan asli daerah (PAD), sekaligus disisi lain kualitas lingkungan hidup tetap terjaga. Namun kenyataan yang terjadi di lapangan, terjadi kerusakan kondisi lingkungan hidup seperti: bantaran sungai menjadi lubang-lubang menganga, adanya pendangkalan sungai, banjir yang sering terjadi, kondisi tebing yang mudah longsor telah mengikis lahan dan mengancam permukiman masyarakat, merusak lahan pertanian, lahan ternak berkurang, serta penyakit ispa ${ }^{1}$.

Maka atas dasar kondisi tersebut di atas, muncul kepermukaan suatu pertanyaan mengapa kebijakan yang dituangkan dalam bentuk Peraturan Daerah Kota Palu Nomor 18 tahun 2003 tentang Pengelolaan Usaha Pertambangan Umum pada tahap implementasinya tidak sesuai dengan amanah isi peraturan daerah itu sendiri. Berdasarkan pengamatan peneliti di lapangan, terdapat berbagai indikasi yang menyebabkan kurang efektifnya implementasi kebijakan tersebut.

Adapun Dinas Pekerjaan Umum, Energi Dan Sumber Daya Mineral Kota Palu dalam menangani berbagai kasus yang berhubungan dengan pertambangan batu dan

1 Laporan Status Lingkungan Hidup Daerah (SLHD) Kota Palu Tahun 2006, diterbitkan Pebruari

2007 oleh Pemerintah Daerah Kota Palu Provinsi Sulawesi Tengah. dampak yang ditimbulkan pada lingkungan hidup masih kurang ditunjang oleh berbagai kelengkapan organisasi dalam melaksanakan perannya itu, seperti sumber daya manusia (SDM) yang dalam hal ini para pegawai pemerintah. Disamping itu, berbagai sumber daya lainnya yang menunjang kegiatan organisasi berupa peralatan yang diperlukan untuk memonitor kegiatan eksploitasi batu sangat minim, seperti kendaraan yang dipergunakan sebagai alat transportasi. Selain itu, upaya sosialisasi tentang kebijakan pengelolaan usaha pertambangan umum masih terasa kurang. Dari informasi yang diperoleh bahwa sosialisasi tentang pentingnya me-miliki rekomendasi Analisis Mengenai Dampak Lingkungan (Amdal), juga masih sangat minim sehingga kondisi ini terus terjadi hingga saat ini ${ }^{2}$.

Kurangnya dukungan partisipasi perusahaan sebagai target kebijakan untuk mematuhi ketentuan yang berlaku dalam peraturan daerah masih rendah, sehingga Dinas Pekerjaan Umum, Energi Dan Sumber Daya Mineral Kota Palu masih terkesan bekerja sendiri dalam implementasi kebijakan tanpa adanya dukungan partisipasi aktif dari perusahaan sebagai pemegang izin. Faktor lingkungan yang turut mempengaruhi, salah satunya faktor ekonomi yang menjadi pendorong utama kegiatan pertambangan batu, dengan tujuan untuk peningkatan Pendapatan Asli Daerah (PAD). Juga terdapat kondisi yang masih saja terus terjadi hingga saat ini yaitu rendahnya pembinaan yang diberikan Dinas Pekerjaan Umum, Energi Dan Sumber Daya Mineral Kota Palu tentang pengelolaan sumber daya alam seperti pertambangan batu dengan memperhatikan keseimbangan kondisi lingkungan hidup. Kondisi tersebut juga dapat diketahui dari laporan mengenai kondisi lingkungan hidup di daerah pertambangan batu yang tidak disampaikan secara kontinu oleh perusahaan pertambangan batu dengan alasan pengisian laporan maupun pembuatan laporan yang belum diketahui.

Disamping itu Dinas Pekerjaan Umum, Energi Dan Sumber Daya Mineral

2 Radar Sulteng edisi Rabu, 23 Juli $2007<$ http://www. radarsulteng.com/berita/> [9/9/07]. 
Kota Palu belum melakukan pemetaan, sehingga belum diketahui seberapa besar potensi material batu dan kerikil yang di wilayah Kota Palu. Baru dilakukan sebatas pemetaan berdasarkan potensi materialnya saja, belum pada pemetaan tentang kondisi lingkungannya, sehingga apabila ada investor yang berniat untuk melakukan aktivitas pertambangan. Barulah bersama instansi lain, seperti Bapedalda meminta kepada investor tersebut, untuk melakukan kajian dari segi lingkungan termasuk masalah sosial dan faktor masyarakat yang berada di sekitar lokasi pertambangan ${ }^{3}$.

Variabel implementasi kebijakan pengelolaan usaha pertambangan umum diukur oleh Smith (1973:202-205) dengan mengemukakan bahwa,

The context of the implementation of policies - the policy relevant components which form the tension generating matrix. I wish to identify four such component which are important in the policy implementation process :

1. The idealized policy, that is the idealized patterns of interaction that those who have defined the policy are attempting to induce.

2. The target groups, defined as those who are required to adopt new patterns of interaction by the policy. They are the people most directly affected by the policy and who must change to meet its demands.

3. The implementing organization, usually a unit of the government bureaucracy, responsible for implementation of the policy.

4. The environmental factor, those elements in the environment that influence or are influenced by the policy implementation. The general public and the various special interest groups are here.

Sedangkan variabel efektivitas penanganan kualitas lingkungan hidup diukur oleh Tangkilisan (2005:342-343) mengungkapkan bahwa,

Tujuan upaya penanganan terhadap lingkungan hidup di daerah didasarkan atas prinsip pelestarian sumber daya lingkungan dan upaya memperbaiki atau meningkatkan

3 Radar Sulteng edisi Sabtu, 17 Januari $2004<\underline{\text { http://www. }}$ radarsulteng.com/berita/> [19/8/08]. kualitas lingkungan hidup. Dari prinsipprinsip tersebut dapat dijabarkan tujuan upaya penanganan dampak lingkungan, yaitu :

1. Terpeliharanya fungsi lingkungan hidup dalam usaha meningkatkan daya dukung dan daya tampung fungsi lingkungan.

2. Pengendalian dan penanggulangan pencemaran yang telah dan diperkirakan akan terjadi.

3. Memperbaiki kualitas lingkungan akibat terjadinya kerusakan sehingga da-pat berfungsi kembali sesuai dengan peruntukannya.

4. Peningkatan informasi tentang kuantitas dan kualitas sumberdaya alam, serta tingkat kerusakan alam dan kemampuan daya dukung alam.

5. Meningkatkan kualitas kelembagaan, sumberdaya manusia dan peranserta masyarakat.

Sedangkan yang menghubungkan kedua variabel tersebut berdasarkan pendapat yang dikemukakan oleh Rosenblom dan Robert (2005:360) bahwa,

In this contex effectiveness will focus on the process of implementation.......... the organization of the effort to implement the policy follow the principles of effective management with regard to (1) structure, (2) personnel, (3) budgeting, (4) decision making, and so on.

Sedangkan Koontz dan O'Donnell (dalam Thompson, 1990:575) yang mengemukakan yang menyatakan bahwa,

Suggest that the following principle determine the potential effectiveness of policies in relation to strategy implementation :

(1) Policies should reflect objectives,

(2) Policies should be consistent,

(3) Policies should be flexible,

(4) The extent to which a policy is mandatory,

(5) Policies should be communication, taught and understood,

(6) Policies should be controlled.

Terdapat pengaruh implementasi kebijakan pengelolaan usaha pertambangan umum terhadap efektivitas penanganan kualitas lingkungan hidup.

Besarnya pengaruh implementasi kebijakan pengelolaan usaha pertambangan 
umum terhadap efektivitas penanganan kualitas lingkungan hidup dideskripsikan oleh idealised policy, target groups, implementing organization, dan environmental factor.

\section{METODE}

Analisis Structural Equation Modeling (SEM) membutuhkan data yang besar, sebagaimana Wuensch (2009:1) mengemukakan, "Simple size, As with factor analysis, you should have lots of data when evaluating a SEM. As usual, there are several rules of thumb". Sedangkan untuk menentukan ukuran sampel minimal sebagai acuan tersedia beberapa rule of thumb. Bentler dan Chou (dalam Bachrudin dan Harapan, 2003:68) menyarankan bahwa rasio antara ukuran sampel dan parameter yang ditaksir adalah 5:1 dan 10:1. Acuan ini juga dikemukakan oleh Mueller dan Hancock (2005:55) bahwa, "The rasio sample size to parameters-to-be-estimated should be at least 5:1, preferably larger". Dengan menggunakan rule of thumb 5:1 dan banyaknya parameter yang akan ditaksir sebanyak 20 maka sampel minimal untuk penelitian ini adalah 100 . Hal ini juga selaras rule of thumb, yaitu antara 100 sampai 150 sampel apabila meng- gunakan metode penaksiran parameter Maximum Likelihood Estimation (MLE) (Hair et. al, 1998:605). Berdasarkan hal tersebut maka sampel yang digunakan dalam penelitian ini sebanyak 135 sebagai sampel dari 190 populasi.

Hipotesis tersebut di atas akan diuji menggunakan teknis analisis structural equation modeling (SEM) karena menunjukkan hubungan kausalitas antar dua buah variabel laten. Dalam hal ini variabel implementasi kebijakan per-tambangan sebagai exogenous latent variable diukur oleh dimensi idealised policy, target groups, implementing organization, dan environmental factor dan variabel efektivitas penanganan kualitas lingkungan hidup sebagai endegenous latent variable diukur oleh dimensi terpeliharanya fungsi lingkungan hidup, pengendalian dan penanggulangan pencemaran, memperbaiki kualitas lingkungan hidup, informasi, kelembagaan dan peranserta masyarakat. Adapun metode estimasi yang digunakan adalah metode Maximum Likelihood Estimation (MLE), sedangkan pengujian

Tabel 1. Hasil penghitungan validitas dan reliabilitas dari variabel implementasi kebijakan pertambangan:

\begin{tabular}{lccccc}
\hline $\begin{array}{c}\text { Dimensi Implementasi Kebijakan } \\
\text { Pertambangan }\left(\xi_{1}\right)\end{array}$ & $\begin{array}{c}\text { Loading } \\
(\mathrm{R})\end{array}$ & Reliabilitas $\left(\mathrm{R}^{2}\right)$ & $\begin{array}{c}\text { Varians } \\
\text { Error }\end{array}$ & t-hitung & Keterangan \\
\hline Idealised Policy $\left(\mathrm{X}_{1}\right)$ & 0.620 & 0.384 & 0.616 & 8.52 & Valid-Reliabel \\
Target Groups $\left(\mathrm{X}_{2}\right)$ & 0.610 & 0.372 & 0.628 & 6.13 & Valid-Reliabel \\
Implementing Organization $\left(\mathrm{X}_{3}\right)$ & 0.690 & 0.476 & 0.524 & 7.80 & Valid-Reliabel \\
Environmental Factor $\left(\mathrm{X}_{4}\right)$ & 0.740 & 0.548 & 0.452 & 8.67 & Valid-Reliabel \\
& \multicolumn{5}{r}{ Reliabilitas } \\
Construct Reliability & \multicolumn{2}{c}{0.7612} & & Reliabel \\
\hline
\end{tabular}

Tabel 2. Hasil penghitungan validitas dan reliabilitas dari variabel efektivitas penanganan kualitas lingkungan hidup:

\begin{tabular}{|c|c|c|c|c|c|}
\hline $\begin{array}{l}\text { Dimensi Efektivitas Penanganan } \\
\text { Kualitas Lingkungan Hidup }\left(\eta_{1}\right)\end{array}$ & Loading & Reliabilitas & $\begin{array}{l}\text { Varians } \\
\text { Error }\end{array}$ & t-hitung & Keterangan \\
\hline $\begin{array}{l}\text { Terpeliharanya Fungsi Lingkun- } \\
\text { gan Hidup }\left(\mathrm{Y}_{1}\right)\end{array}$ & 0.820 & 0.672 & 0.328 & - & Valid-Reliabel \\
\hline $\begin{array}{l}\text { Pengendalian dan penanggulan- } \\
\text { gan pencemaran }\left(\mathrm{Y}_{2}\right)\end{array}$ & 0.770 & 0.593 & 0.407 & 9.34 & Valid-Reliabel \\
\hline $\begin{array}{l}\text { Memperbaiki kualitas lingkungan } \\
\text { hidup }\left(\mathrm{Y}_{3}\right)\end{array}$ & 0.680 & 0.462 & 0.538 & 8.78 & Valid-Reliabel \\
\hline Informasi $\left(\mathrm{Y}_{4}\right)$ & 0.690 & 0.476 & 0.524 & 6.67 & Valid-Reliabel \\
\hline $\begin{array}{l}\text { Kelembagaan dan peranserta } \\
\text { masyarakat }\left(\mathrm{Y}_{5}\right)\end{array}$ & 0.890 & 0.792 & 0.208 & 14.58 & Valid-Reliabel \\
\hline \multicolumn{6}{|c|}{ Reliabilitas } \\
\hline Reliabilitas Construct & \multicolumn{4}{|c|}{0.8809} & Reliabel \\
\hline
\end{tabular}


Tabel 3. Pengujian terkait pada hipotesis penelitian terdapat pengaruh implementasi kebijakan pertambangan terhadap efektivitas penanganan kualitas lingkungan hidup:

\begin{tabular}{|c|c|c|c|c|}
\hline Pengaruh & Koefisien Jalur & t-hitung & t-tabel & Keterangan \\
\hline$\xi_{1} \rightarrow \eta_{1}$ & 0.88 & 8.85 & 1.978 & Terdapat pengaruh yang signifikan \\
\hline
\end{tabular}

kecocokan model dilakukan melalui pengujian secara inferensial yaitu chisquare dan secara deskriptif menggunakan beberapa ukuran Goodness of Fit (GOF). Diperoleh hasil chi-square 22.968 dengan nilai p-value 0.635 , Root Mean Square Error of Approximation $($ RMSEA $)=0.000$, Goodness of Fit Index $(G F I)=0.963$, yang menunjukkan bahwa model fit. Dengan demikian dapat disimpulkan bahwa secara keseluruhan model diterima.

\section{HASIL DAN PEMBAHASAN}

Dinas Pekerjaan Umum, Energi Dan Sumber Daya Mineral Kota Palu dalam mengimplementasikan kebijakan yang sesuai dengan kewenangan yang dimilikinya, masih terjadi lemahnya pembinaan yang berkaitan dengan pengelolaan sumber daya alam seperti kegiatan pertambangan batu yang turut memperhatikan kualitas lingkungan hidup masih terlihat kurang karena yang terjadi di lapangan bahwa terjadi permasalahan lingkungan hidup sebagai dampak dari pertambangan batu. Disamping itu menyangkut laporan, yang seyogianya dapat dilaporkan oleh pihak perusahan penambang batu ternyata tidak terlaksana sebagaimana mestinya. Seperti laporan yang tidak disampaikan secara kontinu oleh pihak perusahaan mengenai kondisi lingkungan hidup di sekitar wilayah pertambangan batu. Dalam hal ini, Dinas Pekerjaan Umum, Energi Dan Sumber Daya Mineral Kota Palu masih acuh.

Disisi lain, kebijakan yang diimplementasikan membutuhkan adanya suatu interaksi yang menjadi bagian dari sebuah proses implementasi kebijakan. Dari interaksi yang dilakukan, diharapkan dapat memberikan suatu perkembangan wawasan dan pemikiran yang lebih baik. Selanjutnya mendorong lahirnya program-program untuk mengimplementasikan kebijakan melalui proses yang bertahap dan fleksibel dengan kondisi yang ada, sehingga kebijakan diharapkan dapat mencapai sasaran. Bila hal tersebut dapat terlaksana maka dimensi idealised policy yang merupakan upaya mengimplementasikan kebijakan dengan tetap menjaga dalam kondisi ideal ataupun sebagaimana yang dicita-citakan, dapat dituangkan ke dalam bentuk programprogram kerja akan terlaksana sebagaimana mestinya. Hal ini sebagaimana Winarno (2007:146) berpendapat bahwa,

Kebijakan publik pernyataan-pernyataan secara luas tentang tujuan, sasaran, dan sarana diterjemahkan ke dalam programprogram tindakan yang dimaksudkan untuk mencapai tujuan-tujuan yang dinyatakan dalam kebijakan. Dengan demikian, berbagai program bisa dikembangkan untuk merespon tujuan-tujuan kebijakan yang sama.

Disamping itu keberadaan program tersebut juga sebagai wujud dari interaksi yang terjadi dalam proses implementasi kebijakan. Interaksi tersebut merupakan interaksi yang dilakukan oleh implementator sejak tahap sosialisasi atau memperkenalkan kebijakan pengelolaan usaha pertambangan umum sebagai kebijakan yang mengatur kegiatan pertambangan batu atau galian lainnya kepada pihak yang menjadi sasaran kebijakan yaitu para pengusaha yang bergerak di bidang penambangan batu tentunya, hingga pada tahap pembinaan dan seterusnya. Dari hal tersebut tentunya akan diketahui sejauhmana kebijakan dapat terimplementasikan, sehingga kebijakan Pemerintah Daerah Kota Palu yang berkaitan dengan pertambangan batu dapat memberikan dampak positif bagi lingkungan hidup. Dalam hal ini kebijakan pertambangan batu mengatur bagaimana pemanfaatan potensi sumber daya alam yang diolah sekaligus memperhatikan kualitas lingkungan hidup. Adapun upaya-upaya yang dilakukan tersebut sebagai tindakan dalam proses implementasi kebijakan, dengan tujuan agar kebijakan pertambangan batu diterima oleh pihak-pihak yang di- 
jadikan sebagai sasaran kebijakan.

Dalam implementasi kebijakan tentunya memiliki target atau sasaran yang nantinya sebagai pelaksana ketentuan di dalam kebijakan. Sehingga yang menjadi target dalam implementasi kebijakan pertambangan batu adalah para pengusaha pemegang izin usaha pertambangan batu. Dalam kedudukannya sebagai target dari implementasi kebijakan, maka diperlukan adanya partisipasi aktif dari para pengusaha pemegang izin usaha pertambangan batu serta mematuhi dan melaksanakan segala ketentuan yang termuat dalam kebijakan tersebut. Agustino (2006:148) mengemukakan bahwa,

Hakekat perhatian publik yang bersifat sesaat menimbulkan kesukarankesukaran tertentu, karena untuk mendorong tingkat keberhasilan suatu implementasi kebijakan sangat dibutuhkan adanya sentuhan dukungan dari warga. Karena itu, mekanisme partisipasi publik sangat penting artinya dalam proses pelaksanaan kebijakan publik di lapangan.

Salah satu bentuk partisipasi aktif dari perusahaan penambang batu, berkaitan dengan informasi mengenai kondisi lingkungan hidup. Hal itu untuk mengukur sejauhmana keberadaan kondisi lingkungan hidup yang menjadi daerah pertambangan batu, serta bagaimana bentuk tindakantindakan secara dini yang telah dilakukan dalam menjaga kualitas lingkungan hidup dan langkah-langkah apa yang akan dilakukan bila ditemukan adanya potensi kerusakan lingkungan hidup. Jadi informasi tersebut dapat dimanfaatkan oleh aparatur maupun bagi masyarakat dan para pengusaha yang mengelola lingkungan hidup dalam bentuk kegiatan pertambangan batu.

Hingga saat ini masih sulit menyerahkan tanggung jawab sepenuhnya pada pihak pengusaha untuk memperhatikan kondisi lingkungan hidup di daerah pertambangan batu tanpa adanya perhatian hingga penekanan yang serius dari pihak Pemerintah Daerah Kota Palu yang teknis dilaksanakan oleh Dinas Pekerjaan Umum, Energi Dan Sumber Daya Mineral Kota Palu. Maka yang perlu diantisipasi adalah dampak dari kondisi lingkungan hidup yang tidak dapat terjaga dengan baik, seperti banjir maupun tanah longsor yang dapat memberikan kerusakan pada berbagai fasilitas umum lainya misalnya jalan dan jembatan, hingga penyakit ispa yang diderita masyarakat yang berada di sekitar lokasi pertambangan batu. Kondisi demikian merupakan gambaran sebagai akibat dari kerusakan lingkungan hidup. Lebih lanjut kerusakan lingkungan hidup juga mengakibatkan semakin memperkecil sumber pendapatan ekonomi. Sebagaimana Salim (1986:6) mengemukakan bahwa:

Langkah kebijaksanaan ecodevelopment mengusahakan keserasian pembangunan dengan pengembangan lingkungan hidup perlu dikembangkan. Faktor pembatas utama adalah kemampuan skill untuk melakukannya.

Disinilah diperlukan adanya hubungan timbal balik sebagai upaya membangun hubungan yang bersinergi antara Dinas Pekerjaan Umum, Energi Dan Sumber Daya Mineral Kota Palu dan para pengusaha penambang batu. Disatu sisi para pengusaha penambang batu memerlukan dukungan Dinas Pekerjaan Umum, Energi Dan Sumber Daya Mineral Kota Palu dalam mengembangkan usaha. Sedangkan disisi yang lain Dinas Pekerjaan Umum, Energi Dan Sumber Daya Mineral Kota Palu memerlukan adanya informasi dari pengusaha mengenai perkembangan usaha dan kondisi lingkungan hidup berada di wilayah pertambangan batu serta peran aktif dalam menjaga sekaligus melestarikan lingkungan hidup.

Informasi meliputi gambaran tentang kondisi lingkungan hidup di daerah wilayah yang penambangan batu, sekaligus pula menjadi bahan dalam menentukan tindakan merehabilitasi maupun menjaga kualitas lingkungan hidup. Dari hasil penelitian ditemukan bahwa fungsi informasi tersebut belum dapat terlaksana sebagaimana yang diharapkan, sebab belum mendapatkan dukungan dari perusahaan sebagai pihak yang melakukan penambangan batu. Dalam hal ini, upaya merehabilitasi kualitas lingkungan hidup bukan menjadi beban Pemerintah Kota Palu semata, namun juga menjadi beban pengusaha pemegang izin 
usaha penambangan batu sebagai pihak yang memanfaatkan potensi sumber daya alam. Jadi para pengusaha tidak lagi hanya dapat memanfaatkan kondisi lingkungan hidup, akan tetapi juga turut memperhatikan kondisi lingkungan hidup dengan sebaik-baiknya. Untuk itu tindakan yang dilakukan dalam merehabilitasi kualitas lingkungan hidup sangat penting bagi suksesnya pelaksanaan pembangunan yang berkelanjutan. Sedangkan pembangunan yang berkelanjutan menjadi salah satu penentu kesejehateraan masyarakat, sebaliknya kesejahteraan masyarakat tidak dapat diwujudkan dalam waktu singkat. Oleh karena itu pembangunan yang berkelanjutan seyogianya terus menerus dilakukan untuk waktu yang panjang dan tak berujung, disamping itu pembangunan yang berkelanjutan untuk jangka panjang sangat membutuhkan kualitas lingkungan hidup yang selalu terjaga dengan baik. Sebagaimana Djajadiningrat dan Melia (2004:20-21) mengungkapkan bahwa,

Prinsip dasar setiap elemen pembangunan berkelanjutan dapat diuraikan menjadi empat hal, yaitu :

(1) Pemerataan, yakni pembangunan berkelanjutan menjamin pemerataan dan keadilan sosial yang mana kepedulian utama dari suatu pembangunan yang berkelanjutan adalah menjawab pertanyaan tentang pemerataan un-tuk generasi masa kini dan generasi mendatang.

(2) Partisipasi.

(3) Keanekaragaman, yakni pembangunan berkelanjutan menghargai keanekaragaman (diversity), yang mana pemeliharaan keanekaragaman hayati adalah persyaratan untuk memastikan bahwa sumber daya alam selalu tersedia secara berkelanjutan untuk masa kini dan masa datang.

(4) Integrasi, yakni pembangunan berkelanjutan menggunakan pendekatan integratif, yang mana pembangunan berkelanjutan mengutamakan keterkaitan antara manusia dengan alam.

(5) Perspektif Jangka Panjang, yakni pembangunan berkelanjutan meminta perspektif jangka panjang, yang mana masyarakat biasanya cenderung menilai masa kini lebih dari masa depan.

Selanjutnya untuk dapat menerima dan menyesuaikan diri dengan kebijakan yang ada, target gorup memiliki karakter yang perlu menjadi perhatian bagi implementator agar kebijakan dapat diterima. Selain itu, kemampuan berkomunikasi juga harus dimiliki implementator, sebab diterima atau tidaknya sebuah kebijakan sangat tergantung pada proses implementasi kebijakan, yang dalam hal ini ditentukan oleh komunikasi yang dilakukan aparatur sebagai implementator kepada target group yaitu para pengusaha penambang batu. Tangkilisan (2003:19) mengemukakan bahwa, "Jika kebijakan harus diimplementasikan secara tepat, ukuran implementasi mesti tidak hanya diterima, namun mereka mesti juga jelas". Disamping itu juga dibutuhkan sumber daya manusia yang sesuai dengan kebutuhan organisasi Dinas Pekerjaan Umum, Energi Dan Sumber Daya Mineral Kota Palu, sebab pada saat ini keberadaan sumber daya manusia yang dimaksud masih sangat minim. Padahal sumber daya manusia memiliki peran penting bagi organisasi sebagai wadah pelaksana kebijakan (implementing organization), sekaligus untuk mencapai keberhasilan implementasi kebijakan.

Walaupun organisasi memiliki sarana dan prasarana yang memadai namun tanpa adanya dukungan sumber daya manusia yang memadai maka sangat sulit mengoperasionalisasikan sistem kerja dengan sebaik-baiknya. Disamping itu minimnya sumber daya lainnya seperti transportasi sebagai peralatan penunjang pekerjaan. Hal tersebut ditambah lagi dengan minimnya sumber daya dana yang dapat digunakan sebagai penunjang pelaksanaan implementasi kebijakan. Padahal sumber daya dana turut menentukan keberhasilan implementasi kebijakan. Sebagaimana Tangkilisan (2003:12) mengemukakan bahwa, "Jika personalia yang bertanggungjawab dalam melaksanakan semua kebijakan kurang sumber daya untuk melakukan sebuah pekerjaan efektif, implementasi tidak akan efektif pula".

Selain itu masalah dukungan lingkungan ekonomi, sosial, dan politik turut 
berpengaruh pada keberhasilan implementasi kebijakan. Dwijowijoto (2008:456458) menyampaikan bahwa,

Pada prinsipnya ada "empat tepat" yang perlu dipenuhi dalam hal keefektifan implementasi kebijakan. Pertama, adalah apakah kebijakannya sendiri sudah tepat. Kedua, adalah tepat pelaksanaannya. Ketiga, adalah tepat target. Keempat, adalah tepat lingkungan. Keempat "tepat" tersebut masih perlu didukung oleh tiga jenis dukungan, yaitu dukungan politik, dukungan strategik, dan dukungan teknis.

Faktor ekonomi masih menjadi tujuan utama setiap kegiatan pertambangan termasuk didalamnya kegiatan pertambangan batu. Adanya kegiatan pertambangan batu diharapkan dapat memberikan pengaruh pada peningkatan Pendapatan Asli Daerah (PAD). Sehingga dengan alasan ekonomi tersebut, maka Pemerintah Daerah Kota Palu memberikan izin kepada perusahaan dalam pengelolaan pertambangan batu, dalam pelaksanaannya terkadang perusahaan pemegang izin pertambangan batu masih saja kurang memperhatikan kondisi lingkungan hidup. Kurangnya perhatian pada kondisi lingkungan hidup dapat berakibat rusaknya lingkungan hidup, yang selanjutnya sangat berpotensi terjadinya bencana alam. Bila telah terjadi bencana alam maka membutuhkan dana yang sangat besar dalam menangani bencana alam dan merehabilitasi lingkungan hidup termasuk didalamnya sosial kemasyarakatan.

Oleh karena itu lingkungan sosial juga turut menjadi penentu bagi keberhasilan implementasi kebijakan. Oleh sebab itu dibutuhkan hubungan yang harmonis antara aparatur, pengusaha, dan masyarakat yang berada di wilayah pertambangan batu. Serta adanya keterlibatan dari pihak legislatif dan Lembaga Swadaya Masyarakat (LSM), keterlibatan tersebut diperlukan sebagai kontrol pelaksanaan implementasi kebijakan serta sejauhmana keberhasilan implementasi kebijakan tersebut terlaksana. Sebagaimana Winarno (2007:145) berpendapat bahwa,

Implementasi sebagai suatu konsep semua kegiatan ini. Sekalipun implementasi merupakan fenomenayang kompleks, konsep itu bisa dipahami sebagai suatu proses, suatu keluaran, dan suatu dampak. Implementasi juga melibatkan sejumlah aktor, organisasi, dan teknik-teknik pengendalian.

Selain hal tersebut tentunya diperlukan pula perhatian pada aspek lainnya. Sebagai wujud perhatian tersebut maka perlu adanya pendekatan-pendekatan dari aparatur kepada para pengusaha penambang batu. Pendekatan tersebut dimaksudkan agar para pengusaha sebagai pemilik modal agar lebih memperhatikan kondisi sosial masyarakat yang berada di sekitar daerah pertambangan batu, seperti adanya program CSR (Corporate Social Responsive) dalam bentuk menyiapkan dan perbaikan fasilitas umum yang telah rusak atau tidak layak pakai atau turut menyediakan fasilitas umum bagi wilayah yang belum memiliki fasilitas umum seperti fasilitas puskesmas atau posyandu yang berkaitan dengan kesehatan, atau menyediakan fasilitas gedung sekolah, perpustakaan sekolah dan berbagai hal yang berkaitan dengan pendidikan, serta para pengusaha juga melakukan transaksi pembelian sebagian hasil usaha pertambangan batu tradisional yang dikelola oleh masyarakat sekitar daerah penambangan batu yang juga berprofesi sebagai penambang batu. Sebagaimana dikemukakan oleh Budihardjo dan Sudanti (1993:196-197) bahwa,

Peran manusia dalam pelestarian alam dapat ditempuh melalui lima jalur, yaitu :

(1) Jalur politis yang berperan adalah kebijakan atau pemerintah, antara lain melalui wahana seperti undang-undang dan peraturan.

(2) Jalur organisasi adalah pengaturan kerjasama antara pemerintah, sektor swasta dan lembaga-lembaga nirlaba atau swadaya masyarakat yang bergulat dalam bidang lingkungan hidup.

(3) Jalur administrasi, dipandang perlu adanya gagasan dan sikap baru, agar pengelolaan lingkungan dapat dilakukan lebih berdaya guna dan berhasil guna, perlu diciptakan teknik-teknik baru untuk mengukur biaya dan manfaat sosial dari prospek-prospek kepentingan umum, dan penilaian kembali secara lebih akurat area-area seperti taman, 
lapangan, dan ruang terbuka.

(4) Jalur profesional, perlu lebih banyak diterapkan dan dikembangkan praktekpraktek rekayasa yang sudah teruji seperti irigasi intensif, pencegahan erosi tanah, penanggulangan hama dengan tanaman ganda atau campuran, peningkatan produktivitas biologis dan sebagainya.

(5) Jalur ilmiah, dalam bentuk studi dan penelitian yang meluas sekaligus mendalam tentang lingkungan hidup.

Bila hal tersebut dapat terjalin dengan baik maka upaya menjaga keseimbangan lingkungan sosial akan tercapai sebab di sekitar wilayah pertambangan batu yang dikelola perusahaan, terdapat masyarakat yang berprofesi sebagai penambang batu tradisional juga turut mengalami peningkatan pendapatan ekonomi dan kesejahteraan. Selain itu bagi masyarakat penambang tradisional dan masyarakat yang berada di sekitar wilayah penambangan batu milik perusahaan juga akan memiliki keterikatan emosional dengan pihak perusahaan pertambangan batu. Dari adanya hubungan timbal balik antara masyarakat dan perusahaan tersebut selanjutnya akan berdampak pada keberlangsungan kegiatan penambangan batu yang dilakukan oleh perusahaan dan disisi lain keberadaan lingkungan hidup juga terjaga dengan sebaikbaiknya, karena masyarakat di sekitar wilayah pertambangan batu dan masyarakat penambang batu tradisional memiliki kepentingan terhadap lingkungan hidup sebagai tempat hidup dan mata pencaharian mereka, serta perusahaan pertambangan batu yang berkegiatan di wilayah mereka yang dapat membantu meningkatkan derajat ekonomi.

Untuk itu environmental factor dalam implementasi kebijakan pada pengertian ini bukan dalam suatu pemahaman pada lingkungan hidup semata, namun lebih pada suatu pengertian lingkungan yang sangat berperan bagi efektifnya proses implementasi kebijakan. Keberadaan lingkungan dalam hal ini dapat dikatakan merupakan faktor strategis secara internal maupun eksternal saat proses implementasi kebijakan pertambangan berlangsung. Maka implementasi kebijakan pertambangan yang dilaksanakan oleh Dinas Pekerjaan Umum, Energi Dan Sumber Daya Mineral Kota Palu perlu memperhatikan peran dimensi environmental factor.

Adapun langkah-langkah membangun interaksi yang lebih baik pada lingkungan internal dan lingkungan eksternal dapat dilaksanakan apabila Dinas Pekerjaan Umum, Energi Dan Sumber Daya Mineral Kota Palu dapat mengoptimalkan kewenangan yang dimilikinya serta turut memperhatikan kewenangan yang dimiliki oleh instansi-instansi lainnya yang berkaitan dengan objek yang sama yaitu pertambangan batu dan lingkungan hidup. Disamping itu mampu melakukan koordinasi dengan sesama instansi pemerintah daerah sebagai upaya mensinergikan kewenangan yang dimiliki dengan kewenangan yang melekat pada instansi lainnya yang juga berhak menangani kegiatan pertambangan batu dan lingkungan hidup. Hal inilah yang semestinya dilakukan pada proses implementasi kebijakan pertambangan. Koordinasi untuk mencapai sinergi dengan pihak yang lain juga terungkap dalam bahasa daerah Kota Palu (Suku Kaili) berbunyi nosarara nosabatutu yang artinya bersaudara dan bersatu. Sekarang menjadi semboyan Pemerintah Daerah Kota Palu.

Dari penelitian menunjukkan bahwa faktor koordinasi turut berperan penting dalam proses implementasi kebijakan pertambangan batu, ketika Dinas Pekerjaan Umum, Energi Dan Sumber Daya Mineral Kota Palu saat menangani proses izin pertambangan batu juga memerlukan adanya peran dari instansi lainnya. Tetapi peran tersebut masih terbatas pada hal-hal tertentu saja, seperti secara administrasi izin usaha pertambangan semestinya juga memperhatikan rekomendasi yang menyangkut lingkungan hidup dari instansi Badan Lingkungan Hidup Kota Palu. Namun yang terjadi adalah lebih banyak menggunakan tim independen di luar instansi Pemerintah Daerah Kota Palu. Dalam hal ini pada proses pembuatan amdal maupun pada 
pembuatan pengelolaan lingkungan hidup atau upaya pemantauan lingkungan hidup (UKL/UPL) ada keterlibatan pihak perguruan tinggi, namun keterlibatan itu tidak berlanjut pada penanganan pertambangan batu di lapangan.

Sedangkan pada pemerintah kecamatan dan pemerintah kelurahan turut berperan pada proses awal administrasi yakni mensosialisasikan akan adanya perusahaan pertambangan batu di wilayah mereka dan selanjutnya mengumpulkan tanda tangan masyarakat sebagai bukti persetujuan masyarakat akan kehadiran perusahaan. Sehingga adanya keterlibatan berbagai instansi yang turut menangani proses izin pertambangan batu maka untuk menangani kegiatan pertambangan batu di lapangan juga dapat dilakukan secara bersama-sama serta mencegah saling lempar tanggungjawab. Sehingga hasil penelitian ini menunjukkan bahwa faktor koordinasi juga berperan dalam proses implementasi kebijakan. Sugandha (1991:12) mengemukakan peran koordinasi bahwa,

Fungsi koordinasi ini demikian pentingnya, apalagi bila administrasi harus berjalan sebagai suatu sistem, sebagai suatu kesatuan yang bulat dari bagian-bagian (sub sistem) yang saling berhubungan, saling menunjang, dan saling bergantung agar administrasi berjalan mencapai tujuannya. Pandangan seperti ini yang disebut pendekatan sistem merupakan alat dan teknik yang dapat membantu administrator.

Hal ini menunjukkan bahwa model implementasi kebijakan menurut Smith yang meliputi idealised policy, target groups, implementing organization, dan environmental factor yang saling ber-hubungan antara satu dengan yang lainnya, sehingga untuk mensinergikan hubungan tersebut diperlukan adanya koordinasi. Diharapkan dengan semakin terjalin sinergi di antara komponen implementasi kebijakan maka proses implementasi kebijakan tetap berada dalam keadaan yang stabil, dari keadaan yang stabil inilah dapat meminimalisir ataupun dapat mencegah potensi ketegangan yaitu konflik atau disharmonis diantara sesama instansi
Pemerintah Daerah Kota Palu yang bila terjadi akan berdampak pada proses implementasi kebijakan tidak berjalan sebagaimana yang diharapkan.

\section{SIMPULAN}

Simpulan pada penelitian ini bahwa implementasi kebijakan pertambangan memiliki pengaruh dan peran yang sangat penting untuk mencapai efektivitas penanganan kualitas lingkungan hidup di Kota Palu. Sehingga bila terjadi perubahan dalam implementasi kebijakan pertambangan akan berdampak terhadap efektivitas penanganan kualitas lingkungan hidup.

Adapun dari keseluruhan dimensi yang mendeskripsikan implementasi kebijakan pertambangan, paling dominan adalah dimensi environmental factor, artinya saat dilakukan implementasi kebijakan pertambangan paling tercermin dari dimensi environmental factor. Sehingga dimensi environmental factor merupakan prioritas dalam implementasi kebijakan pertambangan untuk mencapai efektivitas penanganan kualitas lingkungan hidup di Kota Palu. Disamping itu adanya aspek koordinasi yang turut dibangun bersama dimensi idealised policy, target groups, implementing organization dan environmental factor pada proses implementasi kebijakan pertambangan. Keberadaan koordinasi untuk lebih mendorong sinergi dalam interaksi diantara dimensi implementasi kebijakan sehingga proses implementasi kebijakan dapat berjalan sebagaimana mestinya, sekaligus pula mencegah terjadinya disinteraksi diantara dimensi implementasi kebijakan yang mengakibatkan ketegangan yaitu konflik atau disharmonis pada proses implementasi kebijakan.

\section{DAFTAR PUSTAKA}

Agustino, Leo, 2006, Dasar-Dasar Kebijakan Publik, Bandung : Alfabeta.

Budihardjo, Eko dan Sudanti Hardjohubojo, 1993, Kota Berwawasan Lingkungan, Bandung : Penerbit Alumni.

Djajadiningrat, Surna T. dan Melia Famiola, 2004, Kawasan Industri Berwawasan 
Lingkungan (Eco-Industrial Park) : Fenomena Baru Dalam Membangun Industri Dan Kawasannya Demi Masa Depan Berkelanjutan. Bandung : Rekayasa Sains.

Dwijowijoto, Riant Nugroho, 2008, Public Policy ; Teori Kebijakan - Analisis Kebijakan - Proses Kebijakan, Perumusan, Implementasi, Evaluasi, Revisi, Risk Management Dalam Kebijakan Publik, Kebijakan Sebagai The Fifth Estate - Metode Penelitian Kebijakan, Jakarta : Elex Media Komputindo.

Hair Jr., Joseph F., Rolph E. Anderson, Ronald L.Tatham, William C. Black, 1998, Multivariate Data Analysis, fifth edition, USA : Prentice Hall International, Inc.

Mueller, Ralp O., and Gregory R. Hancock, 2005, Structural Equation Modeling : A First Course Utilizing The Simplis Command Languange, Chicago : SSI Scientific Software International, IL.

Rosenblom, David H. and Robert S. Kravchuk, 2005, Public Administration Understanding Management, Politics, And Law In The Public Sector, New York : The McGraw-Hill Companies, Inc., 1221 Avenue of the Americas, NY 10020.

Salim, Emil, 1986, Pembangunan Berwawasan Lingkungan, Jakarta : Lembaga Penelitian, Pendidikan dan Penerangan Ekonomi dan Sosial (LP3ES).

Sugandha, Dann, 1991, Koordinasi : Alat Pemersatu Gerak Administrasi, Jakarta : Intermedia.

Tangkilisan, Hessel Nogi S., 2003, Implementasi Kebijakan Publik : Transformasi Pikiran George Edwards III, Yogyakarta : Lukman Offset dan Yayasan Pembaruan Administrasi
Publik Indonesia. ,2005, Kebijakan Dan Manajemen Otonomi Daerah, Yogyakarta : Lukman Offset.

Thompson, John L., 1990, Strategic Management : Awareness and Change, London : Chapman and Hall.

Winarno, Budi, 2007, Kebijakan Publik : Teori dan Proses, Yogyakarta : Media Pressindo.

Smith, Thomas B., 1973, The Policy Implementation Process, Policy Sciences 4, pp. 197 - 209., Elsevier Scientific Publishing Company, Amsterdam - Printed in Scotland.

Wuensch, Karl L., 2009, An Introduction to Structural Equation Modeling (SEM), Departement of Psychology, East Carolina University, Greenville, NC USA, November, Melalui <http:// www.gsu.edu/ mkteer/semfaq. html>. [20/4/2011]

Bachrudin, Achmad dan Harapan L. Tobing, 2003, Analisis Data Untuk Penelitian Survai Dengan Menggunakan Lisrel 8 ; Dilengkapi Contoh Kasus, Jurusan Statistika, FMIPA - Universitas Padjadjaran.

Laporan Status Lingkungan Hidup Daerah (SLHD) Kota Palu Tahun 2006, diterbitkan Pebruari 2007 oleh Pemerintah Daerah Kota Palu Provinsi Sulawesi Tengah.

Peraturan Daerah Kota Palu Nomor 18 Tahun 2003 tentang Pengelolaan Usaha Pertambangan Umum.

Radar Sulteng edisi Sabtu, 17 Januari 2004 $<\underline{\text { http://www.radarsulteng.com/ }}$ berita/> [19/8/08].

Radar Sulteng edisi Rabu, 23 Juli 2007 $<$ http://www.radarsulteng.com/ berita/> $[9 / 9 / 07]$. 